\title{
Ageing in Place or Late Life Move? The Malaysian elderly generation housing options
}

\section{Hafiszah Ismail1', Faridah Muhamad Halil2, Aida Wati Zainan Abidin ${ }^{3}$, Mohamad Sufian Hasim 4}

\author{
${ }^{1}$ Centre of Studies for Estate Management, \\ ${ }^{2}$ Centre of Studies for Quantity Surveying, \\ ${ }^{4}$ Centre of Studies for Building Surveying, \\ Faculty of Architecture, Planning and Surveying \\ ${ }^{3}$ Centre of Studies for Statistical and Decision Science, \\ Faculty of Computer and Mathematical Sciences \\ Universiti Teknologi MARA (UiTM), 40450 Shah Alam, Selangor, Malaysia \\ hafiszah@uitm.edu.my, faridahmh@uitm.edu.my, aida@tmsk.uitm.edu.my,moham315@uitm.edu.my
}

\begin{abstract}
The elderly generation is distinctive, and this reflects their housing preferences. This study aims to offer an outline of the Malaysian generational elderly housing preferences. The main objectives of this study; (i) To define elderly; (ii) To classify the features of elderly housing preferences; and (iii) To ascertain the elderly housing preferences by generations. This study applies mixed-method strategy and shown; (i) Health; (ii) Safety; (iii) Convenience; (iv) Community; and (v) Amenity 1as the preferred elderly housing features. This study guides the main actors of property development on the preferred elderly housing by the Malaysian generations.
\end{abstract}

Keywords: Ageing in Place; Generations, Elderly (Senior) housing; Residential Environment Preferences

eISSN 2398-4295 (2020 The Authors. Published for AMER ABRA cE-Bs by e-International Publishing House, Ltd., UK. This is an open access article under the CC BY-NC-ND license (http://creativecommons.org/licenses/bync-nd/4.0/). Peer-review under responsibility of AMER (Association of Malaysian Environment-Behaviour Researchers), ABRA (Association of Behavioural Researchers on Asians) and cE-Bs (Centre for EnvironmentBehaviour Studies), Faculty of Architecture, Planning \& Surveying, Universiti Teknologi MARA, Malaysia.

DOI: http://dx.doi.org/10.21834/ajbes.v5i18.185 


\subsection{Introduction}

Each generation is unique characteristics and thus linked with individually diverse needs and preferences. Generations are distinct categories of population which differentiate based on their age cohorts or their year born. The elderly (senior) generation or the Baby Boomers generation is a cluster of population of 60 years and above of age. The distinctive year born of this generations are as follows; (i) Baby Boomers - born between 1946 to 1961; (ii) Generation X (Gen-X) - born between 1962-1976; Generation Y (Gen-Y) - born between 1977-1999; and Generation Z (Gen-Z) - born after 1992 (Ismail et al., 2019).

The continually escalating numbers of the Elderly (Senior) population or the Baby Boomers generation together with the world population research and investigation on a variety of topic concerning the generation. Continuous statistical data and projections of the elderly (senior) show the importance of this generation to each nation. The numbers of Asia's population aged 60 and over anticipated to increase from 507.95 million (or $11.6 \%$ of the population) in 2015 to $1,293.7$ million (or $24.6 \%$ of the total population) by 2050 (United Nations, 2015). The Malaysian population anticipated rising from 28.6 million (2010) to 41.5 million (2040) (Department of Statistics Malaysia, 2019). The existing numbers of Malaysian aged 60 years and above is estimated to be 1.4 million and projected to increase to 3.3 million in the year 2020 . The Malaysian elderly will also continue to rise to $14.5 \%$ out of the total population by the year 2040 .

Continuous demographic changes, including the rising numbers of the elderly (senior) population will give impact to the housing demand due to the unique needs and preferences of the generation. Notwithstanding the persistent increase of numbers and in comparison to other developed countries, less attention on the Malaysian elderly (senior) housing provisions presently is given. With the growth and improvement of the longevity of the elderly (senior) population in Malaysia (i.e. up to $75+$ years old per person), more effort into specifically catered housing provision is vital. More elderly (senior) housing options or living arrangement for this unique group of generation should be made available urgently to cater the risen numbers of the population. Challenges faced by the elderly should be given an earnest emphasis by providing housing facilities for them (Amiri, 2018). Changes and improvements in terms of granting sufficient housing for a steadily ageing population and creating community environments that are supportive and livable for all are immediately needed (Mohd. Tobi et al., 2017). Therefore, it is time and fundamental for a study on the Malaysian elderly (seniors) housing needs and preferences. This study is vital to support this generation to age in place gracefully, which can also enhance their quality of life through several provisions of specifically tailored or age-specific housing options.

This study aims to offer an outline of the Malaysian generational elderly (senior) housing preferences. The main objectives of this study are: (i) To define elderly (senior); (ii) To classify the features of elderly (senior) housing preferences; and (iii) To ascertain the Malaysian elderly (senior) housing preferences by generations. 


\subsection{Literature Review}

\subsection{The Elderly (Senior) and needs for an age-specific housing concept in Malaysia}

There is a variety of similar age range given to define the elderly (senior) worldwide. In Western societies, the start of old age considered to be coinciding with the age of retirement, which is from 60 to 65 years of age (WHO, 2007). Following the United Nations, World Assembly on Ageing held in Vienna in 1982, in which the age of 60 years and above adopted for deliberating issues on ageing. Malaysia has also taken this age range in formulating and implementing plans for its senior citizens with the present age of 55 years of age (Phillip and Chan, 2002). For the Asian countries, the age group of the elderly (senior) population can be referred to The Association of Southeast Asian Nations' (ASEAN) age scale for the population. ASEAN a political and economic organization consists of ten members' countries including Malaysia, Indonesia, Philippines, Singapore, Thailand, Brunei, Laos, Myanmar and Cambodia defined seniors or elderly are those aged 60 years and above. In relevance, the retirement age in Malaysia used to be 58 years for the public sector and 55 years for the private sector, but this increased to 60 years for both areas since 2014 . Hence, for this study, the terminology used on the Elderly (Senior) generation in Malaysia is referring to those ages 60 years old and above.

The experiences of the elderly (senior) are diverse. Thus, understanding diversity requires a comprehensive analysis of the elderly in various contexts. Continuous discussions by researchers locally and globally made on the consequence of population ageing on each segment of the nation. It includes the effects in retail, financial services, technology (media), tourism, social services, health, care and also housing. The growth of the ageing population and their high purchasing power will in future make one of the most important customer groups and a decisive driver for the success of companies in many industrial sectors (Bloom et al., 2011). The seniors (elderly) are now becoming the unique potential housing consumers with special needs and preferences. In relevance, a key concern of seniors will be the quality of life in their old age. Housing is essential not only because an older person (elderly) needs a secure and comfortable home but also because housing provides a social surrounding for seniors to interact with others in the community. Planning for the housing situation of an ageing population is one of the challenges faced by many countries. The awareness of the importance of the elderly in the community in oversea leads to various conducted studies on elderly housing internationally. In Malaysia, the issues of elderly (senior) housing needs and aspirations are often either ignored or not given proper emphasis. In developed countries especially United States, United Kingdom and Australia various types of age-specific housing concept introduced to the elderly (senior) housing consumers. The elderly (seniors) in those countries have access to various types of age-specific housing options to choose according to their needs and preferences. The age-specific housing concept is also known as the 'Age-Restricted' community, which offered to people aged 50 years old and over. The Age-Restricted Housing Concept can be devised into Assisted and Non-Assisted type of elderly (senior) housing option for elderly (senior) which choices of Independent Living or with Assisted Living arrangement. 
Lim (2012) implied that the understanding of the critical issues surrounding the needs and desires of the elderly is crucial to reform the existing policy and framework for related elderly service provision. There are many housing concepts, and it is possible to classify housing according to different characteristics. Henilane (2016) has developed a general definition of housing concept that can be used in housing policy. The housing is classified by the housing type, size, housing amenities, location, group of the population living in the housing, type of ownership rights, construction period of the housing, energy efficiency indicators; construction materials used in the exterior wall of the housing and by other features (see Table 1).

Table 1: Housing Classifications

\begin{tabular}{|l|l|}
\hline Type of housing classification & Characteristics \\
\hline By housing type & $\begin{array}{l}\text { Room in the apartment Apartment in a multi-apartment residential } \\
\text { building or nonresidential building Multi-apartment residential building } \\
\text { Family house Other }\end{array}$ \\
\hline By housing size & $\begin{array}{l}\text { One room One-room apartment Two-room apartment Three-room } \\
\text { apartment, and more Family house Other }\end{array}$ \\
\hline By housing amenities & $\begin{array}{l}\text { Housing with all amenities. Housing with part of amenities Housing } \\
\text { without amenities }\end{array}$ \\
\hline By housing location & Housing in a city Housing in rural territory \\
\hline $\begin{array}{l}\text { By a group of population living in } \\
\text { the housing }\end{array}$ & Any resident Persons with low-income or other social groups at risk \\
\hline $\begin{array}{l}\text { By type of housing ownership } \\
\text { rights }\end{array}$ & $\begin{array}{l}\text { State-owned housing Municipality-owned housing Natural person's } \\
\text { owned housing Legal person's owned housing Other }\end{array}$ \\
\hline $\begin{array}{l}\text { By construction period of the } \\
\text { housing }\end{array}$ & $\begin{array}{l}\text { Housing build before World War II Housing built from 1945 to 1990 } \\
\text { Housing built from 1990 until now }\end{array}$ \\
\hline $\begin{array}{l}\text { By energy efficiency indicators of } \\
\text { housing }\end{array}$ & $\begin{array}{l}\text { Minimum regulatory energy performance level allowed for new buildings } \\
\text { Minimum regulatory energy performance level allowed for reconstructed } \\
\text { or renovated buildings Almost zero energy consumption housing Other }\end{array}$ \\
\hline $\begin{array}{l}\text { By construction materials used in } \\
\text { the exterior wall of the housing }\end{array}$ & $\begin{array}{l}\text { Brick wall Wood Brick/panel Reinforced concrete / concrete Lightweight } \\
\text { concrete Wood/masonry Other }\end{array}$ \\
\hline
\end{tabular}

(Source: Adapted from Henilane (2016))

\subsection{Ageing in Place, Late Life Move and The Elderly (Senior) Housing Preferences}

Policies for the elderly (senior) and housing in developed countries put the focus on the older person to be remaining integrated into society. The intention to cater to the elderly (senior) population being included in the formulation and implementation of policies that affect their wellbeing (Ambigga et al., 2011). In Malaysia, a multi-sectoral and multidisciplinary approach was required to set up these policies, and they emphasized the sharing of responsibility between government, private sectors, non-government organisations, community and the older people themselves to meet their needs (Wong, 2010). There have been several national policies put in place for older people in Malaysia. The first policy was the National Social Welfare Policy (1990). This policy addressed the need for the care of older persons by families and communities (Wong, 2010). This was later strengthened with the National Policy for the Elderly (1995) with aimed at "creating a society of elderly people who are contented and possess a high sense of self worth and 
dignity, by optimising their self potential and ensuring that they enjoy every opportunity as well as care and protection from members of their family, society and nation" (Ong, 2001). The National Council of Senior Citizen's Organization Malaysia (NACSOM), the Gerontological Association of Malaysia (GEM) and others provide the impetus in developing these policies and services for older people in Malaysia (Poi et al., 2004).

Issues involving the ageing society in each country are unique, resulting in the adoption of various frameworks for ageing throughout the world (Table 2). These frameworks cover a different domain. This domain includes longevity, physical health, activities of daily living, autonomy, psychological well being, social relationships, work participation, financial security, housing, transport, safety, leisure activities, quality of life, age discrimination and attitudes (Minichiello and Coulson, 2006). These frameworks and their attendant policies help guide the development of relevant programmes, facilities and services around them.

Table 2: Various Ageing policy frameworks available globally

\begin{tabular}{|c|c|c|}
\hline $\begin{array}{l}\text { Policy } \\
\text { frameworks }\end{array}$ & Definitions & $\begin{array}{l}\text { Countries } \\
\text { Adopting }\end{array}$ \\
\hline $\begin{array}{l}\text { Active Ageing } \\
\text { (WHO) }\end{array}$ & $\begin{array}{l}\text { Continuing participation in social, economic, cultural, spiritual and civic } \\
\text { affairs by older persons and not just being physically active or mere } \\
\text { participation in the labour force }\end{array}$ & $\begin{array}{l}\text { United } \\
\text { Kingdom and } \\
\text { Europe }\end{array}$ \\
\hline $\begin{array}{l}\text { Active Ageing } \\
\text { (Adapted) }\end{array}$ & $\begin{array}{l}\text { Optimizing opportunities for physical, social, mental well being } \\
\text { throughout life, to extend healthy life expectancy, productivity and good } \\
\text { quality of life as people age }\end{array}$ & Malaysia \\
\hline Healthy Ageing & $\begin{array}{l}\text { All Australians have the opportunity to maximise their physical, social } \\
\text { and mental health throughout life. Population health strategies promote } \\
\text { and support healthy ageing across the lifespan. Information, research } \\
\text { and health care infrastructure is available to help the healthy ageing of } \\
\text { the Australian population }\end{array}$ & Australia \\
\hline $\begin{array}{l}\text { Successful } \\
\text { Ageing }\end{array}$ & $\begin{array}{l}\text { Multiple dimensions of functioning and wellness are measured, and } \\
\text { these include cognitive and affective status, overall physical health, } \\
\text { social functionally and life engagement, including life satisfaction. } \\
\text { These will form the salient determinants of successful ageing }\end{array}$ & Singapore \\
\hline Healthy Ageing & $\begin{array}{l}\text { A lifelong process of optimising opportunities for improving and } \\
\text { preserving health and physical, social and mental wellness, } \\
\text { independence, quality of life and enhancing successful life-course } \\
\text { transitions }\end{array}$ & Canada \\
\hline Positive Ageing & $\begin{array}{l}\text { Shine a positive light on ageing and older persons by recognizing their } \\
\text { potential skills and ability rather than their age }\end{array}$ & New Zealand \\
\hline
\end{tabular}

(Source: Adapted from Ambigga et al., 2011)

The adaptation of Active Ageing in each formulated policy related to the elderly (senior) population is available. According to Ambigga et al., (2011), Active Ageing is related to optimizing opportunities for physical, social, mental well being throughout life, to extend healthy life expectancy, productivity and good quality of life as people age. In relevance, Ageing in Place is the central concept in each discussion or studies on Elderly (Senior) Housing. Initial Ageing in Place concepts created to gain an understanding of the meaning of older persons attached to a place or a physical or emotional space. While the early definitions of ageing in place do not exclusively connect the place with one's own home, 
over the years, the meaning has shifted to be more home-specific. Much of the literature and the field think ageing in place as the ability to remain in one's own home or a community setting over one's life, until old age (Weil \& Smith, 2016). Although the Malaysian senior (elderly) generations preferred to age in place and lived by their own (independently) for in the retirement life stage, however, there is a time where they were 'forced' to move due to the need of to be dependent to others (Ismail et al., 2019). This 'forced move' is also referred to as the 'Late-live move'. The late-life move situation led them to move to other housing location or different types of housing/living arrangement, which is more age-specific (i.e. elderly/senior-specific). The frailty experiences and needs for age-specific/age-restricted housing of the elderly (senior) are also diverse. Thus, understanding of the diversity of needs requires a comprehensive analysis of the elderly in various perspective.

The household motives for moving are said to be varied by age group. The elderly (senior) reasons for moving are quite different from the other younger generations. Households of more than 50 years old of age tend to move less often than the younger households. When they do move (late-life move), they move for distinct or for age-related reasons. For example, households over 70 years old will move to the more age-specific type of housing due to health reasons. Although being 'forced' to move, the desire of the elderly (senior) to be closer to family and friends also rises in importance as the household ages (Mathews, 2007). Sergeant and Ekerdt (2008) further explained late-life move or late life residential mobility as a significant life course event that differs from moves at other life stages in three (3) ways. For example; (1) reason for moving; (2) relocation typically to a smaller home; and (3) household disbandment of a lifetime accumulation of possessions. Late-life moves can be classified according to their triggering mechanism (retirement, moderate, disability and significant chronic disability). They would be expected, if undertaken, to occur sequentially along the life course (Litwak and Longino (1987). The first more is due to positive environmental and lifestyle preferences motivation. It is most often taken by recent retirees who are married, relatively healthy and has sufficient retirement income. The second move is due to the needs for assisted housing or living arrangement. For example, the widowed with increasing chronic disabilities combined with lack of financial resources which can make it difficult for residents to perform everyday household tasks within a traditional house. Those anticipating or experiencing such problems may move to adjust their housing to a lower cost, more manageable dwelling with easier access to services and kin (Friedrich and Warnes, 2000; Longino et al., 1991; Speare and Meyer, 1988). This second assistance move may be either a short-distance move or long-distance return migration into smaller, shared and rental housing (Warnes, 1992a). Finally, the third move often occurs due to severe illness or severe chronic disabilities which push the mover into shared or institutional housing. This move may be local or long-distance (Litwak and Longino, 1987) depending on where it is available for assistance (Gibler et al., 2009). Mathews (2007) earlier relates 'late-life moves' with the elderly (senior) through definition on the 'Boomerang retirees' generation. This generation is individuals who, after moving to an amenity-oriented location, later leave to return to their original community or move closer to 
family. Such moves are mainly triggered by increasing disability or loss of a spouse. Motives behind a late-life residential move are often studied as discrete categories, yet motivation theory stresses interactions across multiple components within contexts that culminate in self-regulation of behaviour (Ekerdt and Sergeant, 2008).

Fig. 1 illustrates how both the elders and family members influence the move decision, and how each is influenced by ecological layers that comprise the context in which the person who moved is experiencing the ageing process. These layers include individual health and functioning, personal beliefs and attitudes, the physical home environment, family influences, and social pressures.

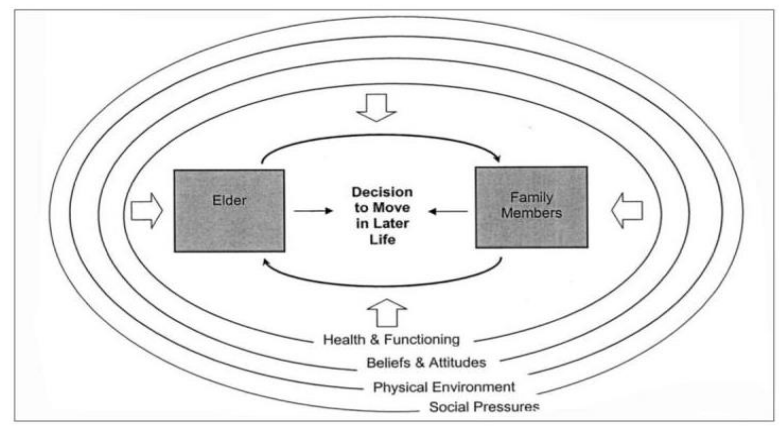

Fig. 1: Model for residential decision-making in later life. (Source: Ekerdt and Sergeant, (2008))

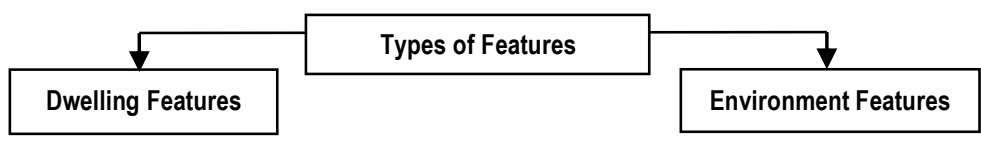

Fig. 2: Types of housing features influencing the elderly (senior) generation (Source: Adapted from Boumeester (2011))

In the Malaysian context, the issues of the elderly (senior) housing needs and aspirations are not given much emphasis and deserted. The understanding of the critical issues surrounding the needs and desires of the elderly is crucial to reform the existing policy and framework related to elderly service provision (Lim, 2012). Buying a house is a multi-elements exercise, involve considering a list of choices or attributes, including tenure options, housing types, neighbourhood, location, etc. Different age category such as elderly or youngster will ascribe different values to these attributes in which, influence their purchasing decision Wang \& Li (2006). Boumeester (2011) (see Fig. 2) has summarized two (2) types of housing features; (i) the dwelling features; and (ii) the environmental features. This model becomes the fundamental framework for developing the features for this study of Malaysian elderly (senior) housing preferences. 


\subsection{Methodology}

Mixed method research strategy via qualitative and quantitative data gathering employed in this study of elderly (senior) housing preferences of the Malaysian generations. A research problem can better understand by the use of mixed-method strategy (qualitative and quantitative) a combination of data collection and analysis in a single study or cycle of studies (Creswell, 2006; Creswell and Plano, 2007. The use of mixed-method strategies in each study provides a better understanding of research problems rather than a single unaided approach. The importance that mixed methods add up to the study can be achieved through numerous basis (Cresswell, 2009). Three (3) primary purpose of data collection in survey research involve interviews, questionnaire administration and observation on people or phenomena (Sekaran and Bougie, 2010). Demographics of the population are the prime factor of property development, particularly for housing provisions that strongly relate with demand and supply of housing. Demographic changes will influence the housing market with the variation of housing needs and preferences. The first data collection conducted via qualitative strategy through interviews with the main actors of property development (local authorities and housing developers in Selangor). Officers from the planning department of 12 local authorities in Selangor (i.e. the City Councils, Municipalities and District Councils) and representatives of prime housing developers in the state interviewed in this study by using structured and semi-structured questions. The interviews were relevant to prove the link between population (generations) growth and the effect of the changes to the property market. This process is also vital to validate two main issues of the study by the expert from the industry. The concerning issues were; (i) the importance of demographics (populations) as one of the prime factors in property development; and (ii) the elderly (senior) housing preferences factors derived from the literature reviews. Next, determinations of the preferred elderly (senior) housing features among Malaysian generations were acquired through quantitative data via survey questionnaires with a total sum of 1,067 respondents of samples for the study. The findings from the quantitative data were significant in observing the differences between needs and preferences of elderly (housing) between Malaysian generations (different age group of housing consumers). The quantitative respondents contacted for this study through several survey strategies that include drop-off, face-to-face interview, postal interview, and internet survey (web-survey). Therefore, this study limited under several grounds; (i) The Case Study - Selangor; (ii) Qualitative - 12 local authorities \& 2 main housing developers in Selangor; (iii) The Malaysian housing consumers preferences - Baby Boomers, Gen-X, Gen-Y and Gen-Z. This paper will present and discuss the quantitative data obtained.

The housing preferences are manifest in the response given by the respondents. Since all the variables measured as categories, analyses based on contingency tables. The study compares the various aspect of current and future housing preference of the four different generational cohorts: Baby Boomers, Generation X, Generation Y and Generation $Z$. Visualization of the patterns of relationships using appropriate graphics provides a better understanding of the relationships between variables. The graphics used are fourfold display which is suitable for a $2 X 2$ table to depict the sample odds ratio. Besides, odds and 
odds ratios are also produced for $2 \times 2$ tables to measure preference likelihood. Odds measured by the ratio of the proportion of an event of interest. First, the preference to age in place. Secondly, the proportion of non-event (other options such as the move to other location is preferred. Odds value higher than one indicates that event of interest is more likely to occur than non-event. The odds ratio is the ratio of two odds. This value is useful when comparing the likelihood that an event is occurring in one group more than in another. For example, we may be interested to know how much more likely that Generation Z would move to another location and live independently compared to Generation Y. Knowledge of this information is vital in future housing planning, especially on the elderly (senior) housing provisions in the Malaysian context.

\subsection{The Malaysian Generational Elderly (Senior) Housing Options}

Each generation, coupled with different needs and preferences. This needs and preferences are due to their generational characteristics differences (Ismail et al., 2019).

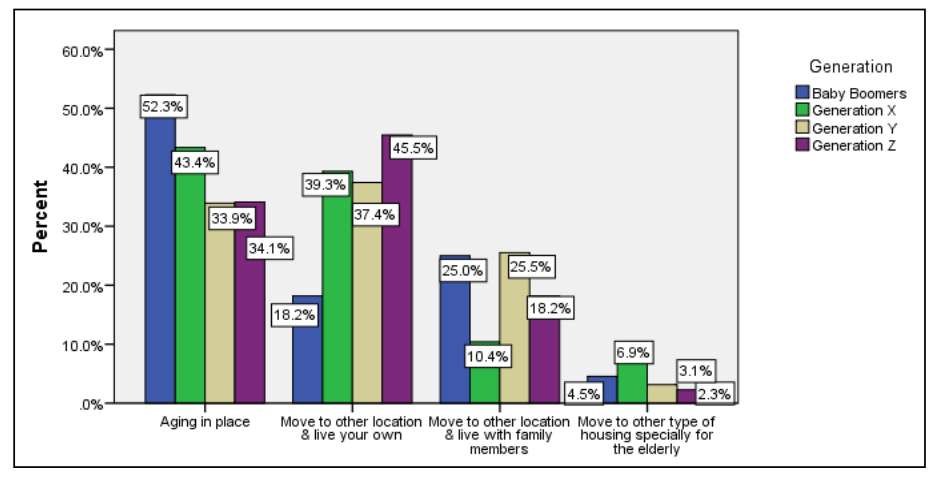

Fig. 3: Preference of Housing Options Based on Generation

Fig. 3 shows the preferred housing options at Senior (Retirement) age of the Malaysian generations. In detail, by generations; most of both the Baby Boomers (52.3 per cent) and Generation X (43.4 per cent) prefers to 'age in place'. As explained by Mathew and Turnbull (2007), the meaning of ageing in place can divide into two categories; (i) Living in a particular home as long as possible, or; (ii) Living in a series of home within a specific community. Therefore, with this finding of high preference to age in place by the Baby Boomers and Generation X show two (2) possibilities. The first possibility of which they prefer to be living in a particular home as long as possible and thus resembles the sense of belonging to home attachment'. The second possibility is they prefer to be living in a series of home in a particular community that resembles the sense of belonging to 'community attachment'. The findings show the Baby Boomers, and the Generation X prefers to be living in the same housing location found for their current, future and senior housing preferences (i.e., the same location under the same local authorities; City Council and Municipal 
Councils). Moreover, findings on the essential attraction factors for future housing (i.e., location, house and neighbourhood) also reveal that both the Baby boomers and Generation $X$ chose neighbourhood as their priority as compared to the other attraction factors. These two (2) previous findings show sign of community attachment.

In contrast, the difference found between these two (2) generations were on their next preferred options of senior housing. The Baby boomers beside the preference to 'age in place' this generation chose to 'move to other location and be living with family members' (25.3 per cent) if they must do so at the senior age. While as for Generation X, their next preferred options were to 'move to other location and live independently' at their senior age. The other two (2) generations of Generation $Y$ and Generation $Z$ also show significant differences in the preferred options of senior housing as compared to the Baby boomers and Generation X. For example, in the majority of the Generation $Y$ (37.4 per cent) and Generation Z (45.5 per cent) chose and put the highest priority and will decide to 'move to other locations and live independently' at the senior age. Also, their next preferred options were to 'age in place' at the senior age (Generation Y - 37.4 per cent and Generation Z 34.1 per cent). The only similarity found were, all of the generations (Baby boomers, Generation X, Generation Y and Generation Z) show the least preferences on the option of 'move to other types of housing specifically for the elderly/senior citizen. The types were referring to the Single-Family Housing, Retirement/Age-Restricted Community, Nursing home'.

Table 3: The Malaysian Generational Housing Options Preferences at Senior Age (Retirement Age)

\begin{tabular}{l|l|l|l|l|l|l}
\hline $\begin{array}{l}\text { Elderly (Senior) } \\
\text { Housing Option }\end{array}$ & $\begin{array}{l}\text { Baby } \\
\text { Boomers } \\
(\mathbf{n = 4 4 )}\end{array}$ & $\begin{array}{l}\text { Generation } \\
\mathbf{X} \\
(\mathbf{n}=173)\end{array}$ & $\begin{array}{l}\text { Generation } \\
\mathbf{Y} \\
(\mathbf{n}=\mathbf{2 8 6})\end{array}$ & $\begin{array}{l}\text { Generation } \\
\mathbf{Z} \\
(\mathbf{n}=44)\end{array}$ & $X^{2}$ & p-value \\
\hline Aging in place & $23(52.3 \%)$ & $75(43.4 \%)$ & $97(33.9 \%)$ & $15(34.1 \%)$ & 8.151 & 0.043 \\
\hline $\begin{array}{l}\text { Move to other location \& } \\
\text { live independently }\end{array}$ & $8(18.2 \%)$ & $68(39.3 \%)$ & $107(37.4 \%)$ & $20(45.5 \%)$ & 8.436 & 0.038 \\
\hline $\begin{array}{l}\text { Move to different location } \\
\text { \& live with family } \\
\text { members }\end{array}$ & $11(25.3 \%)$ & $18(10.4 \%)$ & $73(25.5 \%)$ & $8(18.2 \%)$ & 16.119 & 0.001 \\
\hline $\begin{array}{l}\text { Move to a different type } \\
\text { of housing specifically for } \\
\text { the elderly }\end{array}$ & $2(4.5 \%)$ & $12(6.9 \%)$ & $9(3.1 \%)$ & $1(2.3 \%)$ & 4.200 & 0.241 \\
\hline
\end{tabular}

A chi-square test used to evaluate the statistical significance of the association between generational cohort and their housing preferences at retirement age. Table 3 shows that the option to age in place, move to other location and live independently or move to another location and live with family members are significant. However, the option to move to other types of housing specially designed for the elderly is not statistically significant among the generational cohorts.

Table 4 presents the odds ratio with its associate 95\% confidence in housing options during retirement age for every pair of generations. The table indicates that the odds for Baby Boomers to move to other location and live with family members is 2.87 more likely than the odds of Generation X opted the same. The likelihood of Baby Boomers to ageing in 
place in 2.13 more likely compared to Generation Y. In contrary, the odds for Generation X to move to other location and live independently is 2.92 more likely than the odds of Baby Boomers to opt for the same move. Comparing to Generation Y, Baby Boomers is 2.13 more likely to age in place. The highest odd ratios are for Generation $Z$ against Baby Boomers (3.74) in the likelihood to move to other location and live independently.

Table 4: Odds Ratio ( $95 \% \mathrm{Cl}$ ) for Housing Options between Generations

\begin{tabular}{l|l|l|l|l|l}
\hline \multirow{2}{*}{ Generation } & & \multicolumn{2}{|l}{ Housing Option at Retirement Age } \\
\cline { 3 - 6 } & Relative To & $\begin{array}{l}\text { Ageing in } \\
\text { place }\end{array}$ & $\begin{array}{l}\text { Move to other } \\
\text { location \& live } \\
\text { independently }\end{array}$ & $\begin{array}{l}\text { Move to other } \\
\text { location \& live } \\
\text { with family } \\
\text { members }\end{array}$ & $\begin{array}{l}\text { Move to a } \\
\text { different type of } \\
\text { housing } \\
\text { specifically for } \\
\text { the elderly }\end{array}$ \\
\hline \multirow{3}{*}{ Baby Boomers } & Generation X & $1.43(0.74,2.78)$ & $0.34(0.15,0.78)^{*}$ & $2.87(1.24,6.64)^{*}$ & $0.64(0.14,2.97)$ \\
& Generation Y & $2.13(1.13,4.05)^{*}$ & $0.37(0.17,0.83)^{*}$ & $0.97(0.47,2.02)$ & $1.47(0.31,7.02)$ \\
& Generation Z & $2.12(0.90,5.00)$ & $0.27(0.10,0.70)^{*}$ & $1.50(0.54,4.19)$ & $2.05(0.18,23.44)$ \\
\hline \multirow{3}{*}{ Generation X } & Baby Boomers & $0.70(0.36,1.36)$ & $2.92(1.28,6.67)^{*}$ & $0.35(0.15,0.81)^{*}$ & $1.56(0.34,7.25)$ \\
& Generation Y & $1.49(1.01,2.20)^{*}$ & $1.08(0.74,1.60)$ & $0.34(0.19,0.59)^{*}$ & $2.29(0.95,5.56)$ \\
& Generation Z & $1.48(0.74,2.96)$ & $0.78(0.40,1.52)$ & $2.52(0.21,1.30)$ & $3.21(0.41,25.38)$ \\
\hline \multirow{3}{*}{ Generation Y } & Gaby Boomers & $0.47(0.25,0.89)^{*}$ & $2.69(1.21,5.99)^{*}$ & $1.03(0.49,2.14)$ & $0.68(0.14,3.27)$ \\
& Generation X & $0.67(0.46,0.99)^{*}$ & $0.92(0.63,1.36)$ & $2.95(1.69,5.16)^{*}$ & $0.44(0.18,1.06)$ \\
& Generation Z & $0.99(0.51,1.94)$ & $0.72(0.38,1.36)$ & $1.54(0.69,3.47)$ & $1.40(0.17,11.31)$ \\
\hline & Baby Boomers & $0.47(0.20,1.11)$ & $3.74(1.42,9.90)^{*}$ & $0.67(0.24,1.86)$ & $0.49(0.04,5.59)$ \\
& Generation X & $0.68(0.34,1.35)$ & $1.29(0.66,2.51)$ & $0.40(0.77,4.74)$ & $0.31(0.04,2.47)$ \\
& Generation Y & $1.01(0.52,1.97)$ & $1.39(0.74,2.65)$ & $0.65(0.29,1.46)$ & $0.72(0.09,5.78)$ \\
\hline
\end{tabular}

The fourfold display in Fig. 4 shows the relative preference for housing options between various generations. Since the upper quadrants of all four fourfold plots do not overlap with the lower ones, it means that the odds ratio differ significantly from 1.

In overall, the Malaysian Baby Boomers prefer to age in place, live by their own and to be living near to their family members during the retirement life stage. Mobility in the housing market plunges with age (Ismail et al., 2019). The Elderly (Senior) were less mobile as compared to the younger generations. However, due to specific reason, the Baby Boomers will once again become mobile and move. If this happens, the findings show that the Baby Boomers will move to another location but still prefer to live on their own (independently). They would also move to another location and chooses to be living in with their family members.

Most importantly, although with limitation of Elderly (Senior) housing options in Malaysia the generations show preferences to be living in a specific type of housing for elderly (senior) which also known as the 'Age-Restricted' Housing. The strongest predictor of isolation in old age is living alone (Wu and Chan, 2012). The preferences of the Malaysian generations on the Elderly (Senior) housing options show that the Malaysian generation supports Active Ageing and thus indicates that there will be no sign of 'isolation' in retirement life stage. 

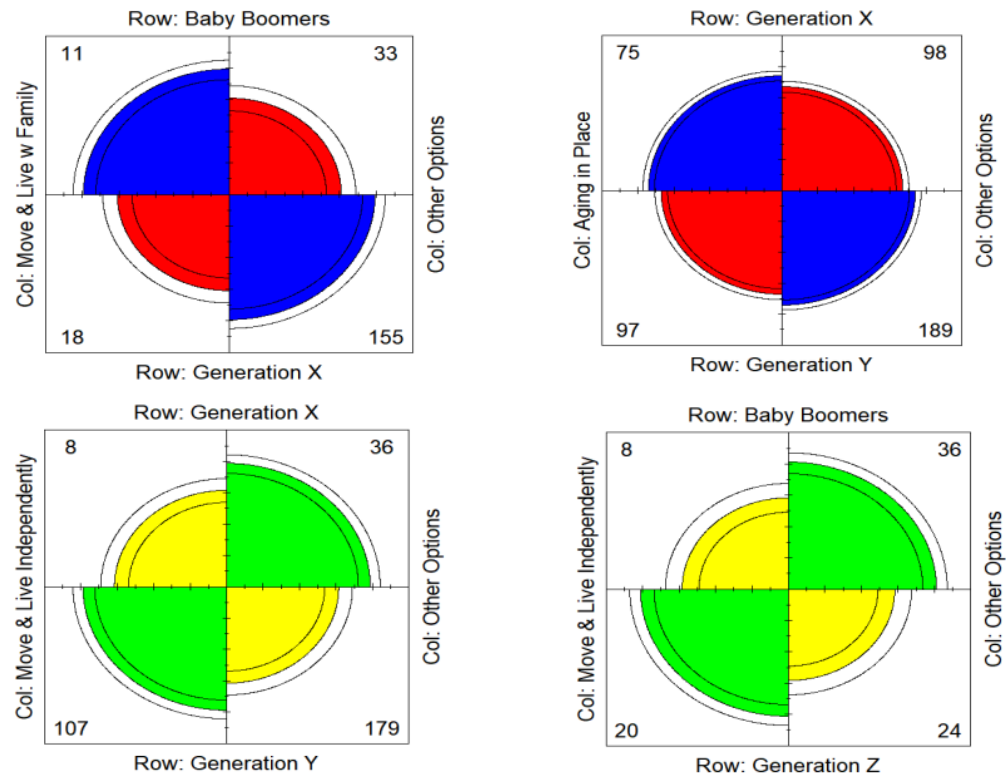

Fig.4: Comparisons of Housing Options between Generations

\subsection{Discussion}

The above findings demonstrate that the Malaysian generational of housing consumers (i.e. Baby Boomers, Generation X, Generation Y and Generation Z) prefer to age in place during their senior age or the retirement life stage. The details of the findings clearly show that older people value ageing in place. Ageing in place is about expressing and retaining a sense of identity, social relationships, and autonomy or independence and choice (World Health Organization 2017). Most older people prefer to continue living in their own homes and live independently for as long as possible (Clark and Davies 1990; Kramer and Pfaffenbach 2016, Ismail et al. 2019). Research shows this linked to the higher attachment of the elderly to their homes, their memories, identity building, and existing social networks in the current living environments (Sixsmith 1990; Dupuis and Thorns 1996; Oswald and Wahl 2005; Clough et al. 2004; Dahlin-Ivanoff et al. 2007; Vasara 2015). Therefore, attachment to a place is an essential factor underpinning older adults' low mobility (De Jong et al. 2012). Promoting Aging in Place (AIP) is a policy objective for both developed and developing countries (World Health Organization, 2007).

The preference of the Malaysian generations to age in place during their elderly (retirement life stage) indicated through the main findings of this study. Therefore, various strategies in different housing aspect are highly needed to cater to the needs of the Malaysian elderly (senior) population. These strategies include the planning of housing 
provisions which is elderly-friendly for this specific generation. Community support networks found to be an essential social, environmental element for AIP (Gardner, 2011). The findings also show the willingness of the generation to move to if they are required to do so. The 'late-life moves' of the generations made with specific reasons. The choices of this 'latelife moves' are; (i) to move to another location and live independently; or/and (ii) to move to other types of housing specifically for the elderly (senior) generation. The preference of to be living independently during elderly age (retirement life stage) accompanied with preference to be living near family members show no sign of isolation tendency among elderly (senior). The elderly (senior) are most happy with family life, especially with their children (Läidmäe et al., 2012). Social support of family is vital to improve the quality of life of the elderly (Chalise, 2010). Research in many cultural settings shown older people prefers to be living in their own homes and communities (WHO, 2011).

In comparison to other developed countries, the most common Elderly (Senior) housing option in Malaysia is the nursing home. The findings from this study reveal the acceptance of the Malaysian generation on the introduction of the elderly (senior) housing living arrangement concept in the Malaysian context. Despite familiarity with the Age-Restricted Housing Concept, the acceptance of the concept shown through the level of preferences on various types of offered concept. The Elderly (Senior) housing concept can devise into Independent and Assisted Elderly (Senior) types of housing. More Elderly (Senior) housing concepts or living arrangement options should be offered and made accessible to encourage active ageing in Malaysia. This action is essential to assist the Elderly (Senior) generation and to able them in adjusting well during their retirement life stage. Baby Boomers are the empty nesters who prefer to be independent. This generation prefers to age in place and tends to stay at the same house in the same neighbourhood for their entire life. Thus, better housing policies for the elderly generations should be made accessible for better elderly housing provisions (Ismail \& Mohamed Shaari, 2019). The Malaysian generational preferences on various types of Age-Restricted Community housing options (i.e. Assisted, Unassisted, Shared and Supported home) versus their familiarity on the concepts indicate the need of specifically tailored elderly (senior) housing concept for Malaysian context (Ismail et al., 2019).

\subsection{Conclusion and Recommendations}

Different age cohorts of population or categories of generations are distinctive and be tied in with own unique characteristics. The uniqueness and dissimilarity of characteristics between generations (i.e. Baby Boomers, Generation X, Generation Y and Generation Z resulted in different needs and preferences and or refer to as generational differences. In relevance, the continuing increase of world population together with the rising numbers of the elderly (senior) population (i.e. Baby Boomers generation) shows a pleasant signal of improvement in the health condition of the population worldwide. The escalating numbers of the elderly (senior) population will intensely affect the housing market and influence the Malaysian housing demand in particular (Ismail, 2019). The senior (elderly) generation or the 'grey hair' 
consumer acknowledged in each segment, and this includes the housing market in specific. As compared to other developed countries and including the neighbouring country like Singapore, the availability of elderly (senior) housing options in Malaysia is still limited. The most common type of elderly (senior) housing option offered in Malaysia is the nursing home. The findings presented in this study offer reliable indication of acceptance by the Malaysian generation on various types of Age-specific/Age-restricted housing options for the elderly (senior) generation. This sign is crucial to persistently hold up the effort in enhancing the quality of life and active ageing for the future elderly (senior) (i.e. Baby Boomers generations) in Malaysia.

This study on the Malaysian elderly (senior) housing preferences contribute valuable information to the main actors of property development (i.e. local authorities and housing developers) on the Age-Restricted Living Arrangement preferred by the Malaysian generations. As a start, with examples from overseas which have established in their provisions of elderly (senior) housing concepts, it is now time for the main Malaysian actors of property development to be offering similar concept with some alteration to be suited with the Malaysian contexts. Collaborations between public and private sectors are vital in providing both better and affordable elderly (senior) housing living arrangements options for the Malaysian generations. It is time for the Malaysian housing providers (public and private sectors) to embed elderly-friendly housing features in every housing developments. This embedment can also be made compulsory to be provided by the housing developers in every dwelling and in each housing environment to guarantee the quality of life of the generation. To avoid isolation of the elderly (senior) generation during the retirement life stage, Multi-Generational Housing Concept with elderly-friendly features can be further introduced and tailored for Malaysian context. This new housing concept is highly significant to guarantee our elderly (senior) generation to age gracefully together with the community without isolation. Further studies on the Elderly-Friendly housing environment features and elderly-friendly housing design features can be conducted in gaining in-depth understanding of the needs and preferences of this unique generation. The continuous increase of the 'grey/silver hair' housing consumers (Elderly/Senior generation) should be taken severe consideration, and proper planning should be made through age-specific housing policy implementation.

\section{Acknowledgement}

The authors would like to express our gratefulness and to thank The Institute of Research, Management and Innovation (IRMI), Universiti Teknologi MARA (UiTM) for the award of funding this study under the Lestari Grant 2018 (600-IRMI 5/3/LESTARI (023/2018)).

\section{References}

Ambigga, K. S., Ramli, A. S., Suthahar, A., Tauhid, N., Clearihan, L., Browning, C. (2011). Bridging the gap in ageing: Translating policies into practice in Malaysian Primary Care. Asia Pacific Family Medicine. 10:2, pp. 1-7. http://www.apfmj.com/content/10/1/2 
Amiri, M. (2018). Problems Faced by Old Age People. The International Journal of Indian Volume 6, Issue 3, pp. $52-62$

Bloom, D.E., Canning, D. and Fink, G. (2011), "Implications of population ageing for economic growth", available at: www.nber.org/papers/w16705.pdf?new_window $1 / 41$

Boumeester, H. J. F. M. (2011). Traditional Housing Demand Research. doi:10.1007/978-90-481-8894-9

Chalise, H. 2010. Social support and its co-relation with loneliness: a cross-cultural study of Nepales older adults. Aging and Human Development, Vol. 71(2) 115-138, 2010

Clark, W. A. V., and S. Davies. 1990. "Elderly Mobility and Mobility Outcomes." Research on Aging 12 (4): 430 462. doi:10.1177/0164027590124004

Clough, R., M. Leamy, V. Miller, and L. Bright. 2004. Housing Decisions in Later Life. New York, NY: Palgrave Macmillan.

Creswell, J. W., \& Plano, Clark, V. L. (2007). Designing and conducting mixed methods research. Thousand Oaks, CA: Sage

Creswell, J.W. (2009). Research Design Qualitative, Quantitative and Mixed Methods Approaches. California: SAGE Publications, Inc.

Dahlin-Ivanoff, S., M. Haak, A. Fänge, and S. Iwarsson. 2007. "The Multiple Meaning of Home as Experienced by Very Old Swedish People." Scandinavian Journal of Occupational Therapy 14 (1): 25-32. doi:10.1080/11038120601151714.

De Jong, P., J. Rouwendal, P. Van Hattum, and A. Brouwer. 2012. "Housing Preferences of an Ageing Population." Investigation in the Diversity among Dutch Older Adults. Netspar Discussion Paper No. 07/2012-024. Available at SSRN: https://ssrn. com/abstract=2120458 or http://dx. doi. org/10.2139/ssrn.2120458.

Dupuis, A., and C. D. Thorns. 1996. "Meanings of Home for Older Homeowners." Housing Studies 11 (4): 485-501. doi:10.1080/02673039608720871

Ekerdt. D. J., Sergeant, J. F. (2008).Motives For Residential Mobility In Later Life Post-Move Perspectives Of Elders And Family Members. International Journal Of Human Development. Vol.66(2).Pp.131-154. Doi: 10.2190/Ag.66.2.C

Friedrich, K. and Warnes, A.M. (2000) 'Understanding contrasts in later life migration patterns: Germany, Britain and the United States', Erdkunde, Vol.54, pp. 108-20

Gardner, P. J. (2011). Natural neighborhood networks: important social networks in the lives of older adults aging in place. Journal of Aging Studies, 25, 263-271. doi:10.1016/j.jaging.2011.03.007

Gibler, K. M., Casado-Diaz M.A., Rodriguez, V. And Taltavull P. (2009). Late life second move housing choices of international retiree migrants. International Journal of Housing Markets and Analysis. Vol.2, No.2. pp190-210

Henilane. I., (2016). Housing Concept And Analysis Of Housing Classification. Baltic Journal of Real Estate Economics and Construction Management. ISSN: 2255-9671, Vol. 4, pp.168-179. 
Ismail, H., Aziz, F. \& Wahab, A. M. (2019). The Elderly (Senior) Housing Options Preferences Among Malaysian Generations. IOP Conference Series: Earth and Environmental Science. ICCRMBEE2019. IOP Conf. Series: Earth and Environmental Science 385 (2019) 012039 IOP Publishing doi:10.1088/1755 1315/385/1/012039

Ismail, H., Shaari, M. S. (2019). Housing decision: the choice between location, house and neighbourhood among malaysian generations. MATEC Web of Conferences 266 (6) (2019):01026. DOI: $10.1051 /$ matecconf/201926601026

Kramer, C., and C. Pfaffenbach. 2009. "Persistence Preferred-On Future Residential (Im)Mobility among the Generation 50plus." Erdkunde 63 (2): 161-172. doi:10.3112/erdkunde.2009.02.04.

Läidmäe, V., Tammsaar, K., Tulva, T. \& Kasepalu. 2012. Quality of Life of Elderly in Estonia. The Internet Journal of Geriatrics and Gerontology. Vol 7. No 1, 2012

Lim, C. K. (2012). The changing needs of older Malaysians: a Selangor case study.(Doctoral dissertation, Adelaide: University of Adelaide).

Litwak, E. and Longino, C.F. Jr (1987), 'Migration patterns among the elderly: a developmental perspective", Gerontologist, Vol.27, No.3, pp. 266-72.

Longino, C.F. Jr, Jackson, D.A., Zimmerman, R .S. and Bradsher, J. E. (1991). The second move: health and geographic mobility'. Journal of Gerontology: Social Sciences, Vol. 46, pp. 191-213

Mathews, W.J. (2007) 'Housing the Aging Baby Boomer Generation: Implications for Georgia Communities'. Andrew Young School of Policy Studies, Georgia's Aging Population: What to Expect and How to Cope Conference. September 26, 2007. Georgia State University, Atlanta.

Minichiello, V., Coulson, I. (2006). Contemporary issues in gerontology: promoting positive ageing. Sydney: Allen and Unwin

Mohd Tobi, S. U., Fathi, M. S., Amaratunga, D. (2017). Ageing in Place, an overview for the Elderly in Malaysia. AIP Conference Proceedings 1891, 020101 (2017); https://doi.org/10.1063/1.5005434

Ong, F. S. (2001). Ageing in Malaysia: a review of national policies and programmes. Ageing and Long Term Care: The International Development Research Centre (IRDC).

Oswald, F., and H. W. Wahl. 2005. "Dimensions of the Meaning of Home in Later Life." In Home and Identity in Later Life. International perspectives, edited by G. D. Rowles and H. Chaudhury, 21-46, New York: Springer

Phillips D.R and Chan A.C.M (2002), Ageing and Long Term Care, National Policies in the Asia Pacific. Asia Pacific Institute of Ageing Studies. Hong Kong.

Poi, P. J. H., Forsyth, D. R., Chan, D. K. Y. (2004). Services for older people in Malaysia: issues and challenges. Age and Ageing Journal, 33:444-6.

Sixsmith, A. J. 1990. "The Meaning and Experience of Home in Later Life." In Welfare and the Ageing Experience, edited by B. Bytheway and J. Johnson, 172-192. Aldershot: Avebury.

Speare, A. and Meyer, J.W. (1988) 'Types of elderly residential mobility and their determinants'. Journal of Gerontology, Vol.43, No.3, pp.S74-81

Vasara, P. 2015. "Not Ageing in Place: Negotiating Meanings of Residency in Age-Related Housing." Journal of Aging Studies 35: 55-64. doi:10.1016/j.jaging.2015.07.004. 
Ismail, H., et.al./ Asian Journal of Behavioural Studies (AjBeS), 5(18), Jan/Apr 2020 (pp.1-17)

Wang, D., \& Li, S. (2006). Socio-economic differentials and stated housing preferences in Guangzhou, China, 30, 305-326. doi:10.1016/j.habitatint.2004.02.009

Warnes, A.M. (1992a) 'Age-related variation and temporal change in elderly migration', in Rogers, A. (Ed.), Elderly Migration and Population Redistribution: Comparative Study, Belhaven, London, pp.35-55

Weil, J. and Smith, E. (2016). Revaluating aging in place: from traditional definitions to the continuum of care. Working with Older People, Vol. 20 Issue: 4, pp.223-230

Wong, C. N. (2010): Policy response for the aging in Malaysia. Malaysian Institute of Economic Research; 2010 [http://www.mof.go.jp/jouhou/soken/kenkyu/ h18/s2_02.pdf]

World Health Organization (2011). Global Health and Ageing. www.nia.nih.gov/sites/default/files/global_health_and_aging.pdf

World Health Organization (2017) Global strategy and action plan on ageing and health https://www.WorldHealthOrganization.int/ageing/global-strategy/en/.

World Health Organization (WHO) (2007), Global Age-Friendly Cities: A Guide, Geneva, Switzerland, available at: www.who.int/ageing/publications/Global_age_friendly_cities_Guide_English.pdf

World Health Organization. (2007). Global age-friendly cities: a guide. Geneva, Switzerland: WHO. 